the Service in the Civil Estimates for 1959-60 and another $\mathfrak{£ 0 , 0 0 0}$ for capital expenditure on buildings. Replying to Lord Taylor, who paid tribute to the immense amount of research carried out by the Service (estimated at about one-quarter of its work), Lord Hailsham readily gave the assurance requested that its research activities would not be curtailed.

\section{British Overseas Information Services}

IN the House of Commons on February 1, the Chancellor of the Duchy of Lancaster, Dr. C. Hill, gave the estimated cost of the overseas information services during $1959-60$ as $£ 16,966,140$, of which $30 \cdot 3$ per cent was attributable to the British Council, 39 per cent to the British Broadcasting Corporation's External Services, 18.3 per cent to the Foreign Office, 8.4 per cent to the Commonwealth Relations Office, and 3.7 per cent to the Colonial Office. There were 117 United Kingdom information posts overseas, of which nine were staffed by one United Kingdombased officer only, and three by one locally-recruited officer only.

\section{Research and Industry in Great Britain}

Is reply to a question in the House of Commons on February 4, the Minister of Education, Sir David Eccles, as representing the Minister for Science, said that the research needs of the printing machinery, textile machinery and shipbuilding industries were among those being considered for special study by the Department of Scientific and Industrial Research. Since the full co-operation of the firms concerned was essential, an inquiry on a confidential basis was proposed. The report would afterwards be discussed by the industry and steps taken to remedy any defects.

Courses on Nuclear Energy for Engineers and Technical Industrialists

Two international courses on nuclear energy, designed for senior engineers and technical industrialists, are being arranged this summer by the European Nuclear Energy Agency of the Organization for European Economic Co-operation. One course will be at the Centre d'Etudes Nucleaires at Saclay (France) and the other at the Atomic Energy Research Establishment, Harwell. Each will be open to some fifty participants from countries belonging to the Organization, and will cover the technical, economic and industrial aspects of nuclear energy. The course at Saclay (in French) will be held during June 27 July 8; the Harwell course (in English) during July 4-15. The programme in each case will comprise lectures, practical work and visits to installations, and will be presented throughout from the point of view of the engineor and the industrialist. Further information can be obtained from O.E.E.C. European Nuclear Energy Agency, 38 Boulevard Suchet, Paris 16.

\section{Courses in Advanced Technology}

THE wide range of part-time courses dealing with advanced aspects of technology provided by technical institutions in the London area is described in a bulletin prepared by the London and Home Counties Regional Advisory Council for Technological Education. At Balham and Tooting College of Commerce experts from foreign embassies were invited to discuss the problems of British export policy. A course on energy approximations in structural design was arranged at Battersea College of Technology, while at the Borough Polytechnic bakery sales manageresses were invited to learn how better to sell bakery products. Joinery estimating was available for joinery managors and shop foremen at the Brixton School of Building, and new developments in gas chromatography were available at the Brunel College of Technology. At the City of London College senior executives of tanker operating firms were invited to a series of lectures on the economics of tanker shipping operations. Further details of the bulletin can be obtained from the Secretary, Regional Advisory Council, Tavistock House South, Tavistock Square, London, W.C.1.

\section{The Leopoldina German Academy of Sciences: Elections}

THE Deutsche Akademie der Naturforscher Leopoldina, Halle, recently elected the following new members, in the sections indicated: Zoology, Prof. G. P. Baerends (Haren (Gron.) Holland), Prof. Willi Hennig (Berlin), Prof. Werner Jacobs (Munich), Dr. Martin Lindauer (Munich), Prof. Hans J. Müller (Quedlinburg), Dr. Johann Schwartzkopff (Munich), Prof. Niko Tinbergen (Oxford); Physical Chemistry, Prof. Gustav Kortüm (Tübingen), Prof. Werner O. Köster (Stuttgart); Internal Medicine, Prof. Ferdinand Hoff (Frankfurt/M.), Prof. Hugo Wilhelm Knipping (Cologne), Prof. Ernst von Lauda (Vienna), Prof. Paul Martini (Bonn), Prof. Helmuth Reinwein (Kiel), Prof. Rudolf Schoen (Göttingen).

\section{Clough Memorial (Geological) Research Fund}

The Clough Memorial Research Fund of the Edinburgh Geological Society is availablo for geological research in Scotland and the North of England (Northumberland, Durham, Cumberland, Westmorland and Yorkshire). Grants for the period April 1, 1960-March 31, 1961, will be made shortly, and applications, stating the nature of the proposed research, should be sent before March 31 to the Secretary, Clough Memorial Research Fund Cornmitteo, Edinburgh Geological Socioty, Synod Hall, Castle Terrace, Edinburgh 1.

\section{University News :}

London

Dr. H. O. Schild, reader in pharmacology at University College, has been appointed to the University chair of pharmacology tenable at that College, as from October 1, 1961; and Dr. W. F. Widdas, reader in physiology at King's College, has been appointed to the University chair of physiology tenable at Bedford College, as from October $1,1960$. The following appointments are also announced : Dr. H. Lehmann, senior lecturer in chemical pathology at St. Bartholomew's Hospital Medical College, to the University readership in chemical pathology tenable at that College; and the title of reader in chemical pathology in the University of London on Dr. G. R. Webster in respect of his post at Guy's Hospital Medical School.

\section{Oxford}

$I_{T}$ is announced that the Forestry Commission is to make a grant not exceeding $£ 4,000$ for two years beginning April 1, 1960, for the continuation of an investigation into the costa of private forestry and oconomic information concerning private forestry estates in England and Wales, being carried out in the Department of Forestry under the direction of J. J. MacGregor. 